\title{
BEYOND NEOLIBERALISM, THE EMERGENCE OF LATIN AMERICA PINK TIDE (POST WASHINGTON CONSENSUS AND NEOSTRUCTURALISM)
}

\author{
Muhammad Dudi Hari Saputra \\ Dosen Universitas Kutai Kartanegara \\ Email : dudisaputra@gmail.com
}

\begin{abstract}
This paper aims to analyze the emergence of Latin America Pink Tide and others, especially in politicaleconomic paradigm (liberalism, neoliberalism and post-neoliberalism). Firstly, this paper describes an international political economy development generally and theoretically. Secondly, it describes political economy conditions in Latin America. Thirdly, it analyzes neoliberalism context that affects the development process in Latin America countries. Fourthly, it analyzes neoliberal development model, which is adopted in the context of Latin America. Fifthly, author is trying to address alternatives of neoliberalism development model that was conceived and adopted by the countries in Latin America, associate with pink tide phenomenon that recently emerging up in most countries in Latin America.
\end{abstract}

Keywords: Alternative model, Development, International Political Economy, Latin America, Liberalism, Neoliberalism, Post-neoliberalism and Pink Tide.

\section{INTRODUCTION OVERVIEW OF INTERNATIONAL POLITICAL ECONOMY}

International political economy had been scientifically standardized and regarded as studies at several universities in America and Europe began in the 1970s and 1980s, as a response to the oil embargoed events by OPEC countries. Political economy studies later confirmed no separation of economics and politics, and vice versa. Although, according to Riza Noer Afani (2013), a close relation of political economy is not something new, only then separated by the scientific method of behaviorism/positivism.

The definition of political economy, according to some researchers is the analysis of the relationship between economics and international politics (John Bayliss and Steve Smith: 2008) or the economic and political relations in the global level (World) (Richard W. Mansbach and Kirsten L. Rafferty: 2008)

Study of international political economy has developed very rapidly; issues of international relations began to shift from high issue (defense and security) to the low issue (economy and politic). Of course, this affected the scope of disciplines and international political economic phenomenon, which became the main focus of international relations. Globalization is also one of the main factors of the growing discussion related to international political economy importance, especially in the realm of development method in developing countries, thus it is important to understand the dynamics of correlation 
between development strategies of economic globalization process which have been undertaken by developing countries and exploring development models that have been already developed.

The definition of globalization itself is: "a together and sustain process that weaves people everywhere, resulting interdependence worldwide with fast flow motion and massive either by humans, goods, and ideas across national borders" (Richard W. Mansbach and Kirsten L. Rafferty: 2008).

Referring to the above definition we can understand the complexity of the translation of the international political economy. Scientific foundation of international political economy is based on three main approaches tradition: Mercantilism, Liberalism and Marxism (Thomas Oatley, 2003), and was eventually deemed irrelevant because the approach is based only on the roots of ideology and based on the significance of actors, i.e. Liberal: individual, Mercantilist: State and Marxism: Social Class. In this context, author will be outlined several points of view of political economy in the perspective of international relations in Latin America.

\section{OVERVIEW OF POLITICAL ECONOMY CONDITIONS IN LATIN AMERICA}

Latin America geographically covers the countries of Central America, the Caribbean and South America, with Mexico in the northern part and Argentina or Chile in the most southern part. Latin America countries also can be classified based on culture and religion that is so influenced by the tradition of Spanish and Portuguese (especially Brazil). In the economy, Latin America countries are categorized as developing countries (South) with absolute excellence and economic power still rely on natural resources or raw materials.

According to Robert Gwynne and Cristobal Kay's book, Latin America Transformed: Globalization and Modernity; explained the economic conditions of countries in Latin America from 1970s until 2000s are still far behind compare to industrialized countries that have been developed such as the US, Japan, Germany, United Kingdom and Italy. GNP per capita figures are still lower, and causing major problems in Latin America towards how to build a genuine model of development that suitable with the Latin America's economic condition, thus can be implemented. 
At first, the process of development in Latin America are affected by the approach that taken by economists with modernization theory, such as WW Rostow with his famous book "The Stages of Economic Development"; which stages level of economic development into (1) traditional society, (2) pre-conditions of the take-off, (3) take-off, (4) the drive to maturity, (5) age of high mass consumption, and the key to reach the take-off stage for Latin America is spend 10-20 per cent of national income for savings/investments and arrange development programs annually (usually every 5 years) with a capital investment targets both the private sector or state-controlled and focused on leading sectors such as large industrial and energy.

However, this approach is considered less work effectively because the data report reveals that South American countries are still struggling in underdeveloped and developing economy condition and must compete to countries that have been developed in the northern hemisphere. Then, evaluation was brought by an expert on the political economy, who is heavily influenced by Karl Marx, his name is Imannuel Wallerstein (2004), who attempted to explain that the spirit of capitalism brought by Rostow actually evolved from the Europe feudal economic system in the XII-XVI centuries and has established many powerful countries, Wallerstein assess that the characteristics of this system will form a striking difference between rich countries territories and they are much poorer (read: colonization territories). Wallerstein then divide the world based on economic relations into four forms, (1) the core-state (2) semi-periphery, (3) periphery, and (4) external.

In his presentation, the core-states are located in Europe and North America, which will always try to exploit and take advantage of natural resources owned by the periphery countries in Asia, Africa and Latin America. Despite the fact that colonialism formally gone but the exploitation of developed countries to poor and developing countries still continue in the form of neo-colonialism. An Orientalist like Edward Said (1979) has even strengthened the Wallerstein arguments by stating that the structure of the Western powers that control the media and science is one of the dominant factors, hence this phenomenon is continuing.

Imannuel Wallerstein actual inspiration of his theory came from Raul Prebisch (1959) a dependency expert economist from Argentina, Theotonio dos Santos (1970), a Brazilian economist and Andre Gunder Frank (1967) a sociologist from Germany. Point of dependency theory states that poor countries and developing will not be able to improve 
their welfare as long as still in the inferior position of international trade. Dependence of Latin America's poor and developing economies to developed countries are caused by:

1. Dependence on raw materials sector as a trade top priority puts added value produced by the developing countries will never be able to exceed the developed countries, therefore export much higher the materials for having more added value.

2. In addition, the most raw material exports of Latin America are destined to developed countries, therefore if the developed countries experienced a bit of a crisis, the impact of the crisis will have a major impact in Latin America.

3. Dependence on foreign capital debt is very high, causing a large load of debt and is able to drain the state treasury, in addition to the foreign investors are easily to withdraw their capital from Latin America if a time of economic turmoil.

Therefore, the dependency economists' theorists suggest a few things to reduce that dependence:

1. Reduce or limit, even to the self-closing stage of imported goods

2. As much as possible become an independent state (self-sufficient)

3. Creating State control/strong government in the economy

At first the development of this theory was quite good, until entering the culminating point in the 1980s where Latin America experienced a severe economic crisis due to inefficiency and shrunk of national industries that were supported by the government. In order to rebuild the industries, the government requires substantial funds, therefore must borrowed foreign debt. The increase in the debt ratio creates economic crisis in Latin America, that greatly impact on the real sector of monetary and fiscal. The impact of the crisis has established to a new approach, which is too neoliberal.

A general overview of some above description then raises several questions; (1) How true this neoliberal context affects the development process in the countries of Latin America (2) What factors contributed to the development of the neoliberal approach and how its development in Latin America (3) Are there alternative economic development besides neoliberalism development model, which need to be initiated and developed by the Latin America countries, especially if associated with the phenomenon of the pink tide. 


\section{ANALYZES OF NEOLIBERALISM CONTEXT THAT AFFECT THE DEVELOPMENT PROCESS IN LATIN AMERICA COUNTRIES.}

As the author described above, there is one reason for the inclusion of neoliberals development process in Latin America, it because a "failure" of dependence theory in economic development. Spirit promoted by the Neoliberalism cannot be released from the successor of liberalism, which was developed by Immanuel Kant (2001), as philosopher and also an expert in international relations. Kant outlines his thoughts on the state of the world in the writings of Perpetual Peace (Immortal Peace), Kant argued that the democratic/liberal capable of creating peace in the world, although there are sovereign governments for many countries or nations, as long as maintain mutual recognition of sovereignty and implement egalitarian principles that respect rights and interests between the two States or more.

Mansbach added that liberalism is essentially "An optimistic approach to global politics based on the perfectibility of humankind, free trade, and democracy; focuses on individuals rather than states". Hence, from this terminology Neoliberalism is developed as "The system level and assume that actors are both unitary and rational in the sense of judging alternatives on the basis of their costs and benefits. They emphasize that individuals everywhere depend on one another for survival and well-being and that they are linked by shared fates; that is, they are interdependent. Interdependence, in turn, produces cooperation".

In the progress, this neoliberalism is characteristic by advanced industrialized countries and international institutions such as IMF or World Bank, and neoliberalism has also become synonymous with an economic package offered by John Williamson (1989) with 10 points, known as the "Washington Consensus";

1. Fiscal policy discipline, with avoidance of large fiscal deficits relative to GDP;

2. Redirection of public spending from subsidies ("especially indiscriminate subsidies") toward broad-based provision of key pro-growth, pro-poor services like primary education, primary health care and infrastructure investment;

3. Tax reform, broadening the tax base and adopting moderate marginal tax rates;

4. Interest rates that are market determined and positive (but moderate) in real terms;

5. Competitive exchange rates;

6. Trade liberalization: liberalization of imports, with particular emphasis on elimination of quantitative restrictions (licensing, etc.); any trade protection to be 
provided by low and relatively uniform tariffs;

7. Liberalization of inward foreign direct investment;

8. Privatization of state enterprises;

9. Deregulation: abolition of regulations that impede market entry or restrict competition, except for those justified on safety, environmental and consumer protection grounds, and prudential oversight of financial institutions;

10. Legal security for property rights.

In the context of South America, the use of neoliberalism has become a common foundation, and it caused by two main factors:

1. External factors: Robert Gwynne and Christobal Klay explained that the inclusion of Neoliberalism as a method of economic development in South America due to global factors, namely the collapse of the eastern bloc power of the Soviet Union, became marked the success of liberalism and neoliberalism (US and EU) and the failure of Communism/Marxism as methods of economic development, and also the success of economic development in East Asia led-export oriented. And it also certain the use of neoliberalism model forced by the IMF and the World Bank, thus many countries then apply the neoliberal receipt as bailout compensation from the IMF/World Bank.

2. Internal factors: internal factors conducted by the failure of the dependence economic model and structuralism (socialism) in creating development and prosperity in Latin America, especially after the economic crisis, while the neoliberal model with the solution offered by IMF has managed to improve the flow and the amount of trade by other region countries to Latin America countries, and also increasing the amount of investment and high income to banks in South America. In addition, the political factors also have important role, to start change authoritarian military regime in Latin American countries to the democracy leadership system.

\section{NEOLIBERAL DEVELOPMENT MODEL, WHICH IS ADAPTED IN THE CONTEXT OF LATIN AMERICA}

Citing Soe Hok Gie (1983); that every thought from the outside will assimilate with local values, and then it also occurs in Latin America when implementing neoliberal policies. Neoliberalism also not fully provide guarantees of established system/model, even in 2001 Argentina hit by the economic crisis caused by the floating foreign exchange 
market too, therefore Argentina began to apply the fixed currency policy, for this Susan Strange provide criticism, that that globalization is real. It can be exaggerated, but change there undoubtedly has been. State power, on the other hand, still exists and can be - and has been - used to limit the local consequences of globalization. The erosion of national controls over banks and non-banks however, shows that this state power is increasingly shared with markets, enterprises and non-state authorities. And "Our problem in the next century is that the traditional authority of the nation state is not up to the job of managing mad international money, yet its leaders are instinctively reluctant to entrust that job to unelected, unaccountable bureaucrats . . . Perhaps, therefore, money has to become really much more mad and bad before the experience changes preferences and policies" (Mad Money, 1998)

The model of Neoliberalism received sharp criticism from activists and economists from the US itself, such as Jeffrey Sachs (2005), Joseph Stiglitz (2002) and Dani Rodrik (2006). Jeffrey Sachs explains that the solution of Washington Consensus neoliberalism is not a rational solution, but it's like 10 Words of God (the Ten Commandments), as well as Joseph Stiglitz explains that looks very silly when a solution is offered to countries that hit crisis only by economic prescriptions of the Washington Consensus regardless of the symptoms of the patient's have, even Dani Rodrik said that the Washington Consensus has demonstrated its failure and the time for us to say: Goodbye Washington Consensus, Hello Washington Confusion?

John Williamson itself (2003) revealed that his biggest mistake by giving the name of the Washington Consensus for economic solutions. South American countries, in principle, still use the neoliberal economic models such as macroeconomic stability and the protection of individual ownership, but these countries then optimize the income earned by the state to help the poor and education provision.

\section{ALTERNATIVES OF NEOLIBERALISM DEVELOPMENT MODEL THAT WAS CONCEIVED AND ADOPTED BY THE COUNTRIES IN LATIN AMERICA. ASSOCIATE WITH PINK TIDE PHENOMENON THAT RECENTLY EMERGING UP IN MOST COUNTRIES IN LATIN AMERICA.}

Development of the Pink Tide (pink) and another alternative model of economic development besides neoliberalism can not be separated from two things, the first is the victory that earned by the center-left parties in the general election contest and became head of states in Latin America which ultimately have an impact on economic policy 
model. In addition, the second factor is the internal weakness of the neoliberal economic model, which is too oriented on the market and still vulnerable to the economic crisis. Therefore, The countries in Latin America began to look for other alternatives in the economic development model and this paves the way to the pink tide models, which are not trapped in ideological conflict or change slogan/revolution but rather to involve the participation of all parties in the development of the economy; liberal-socialist democratic. Toward this, writer will divide it into two alternatives; the first alternative is the Post Washington Consensus and the second, Neostructuralism.

The first is the PWC or Post Washington Consensus promoted by some South American economy researchers, includes Francisco Panizza (2009) who said; "the PWC is a more comprehensive, context-sensitive and politically aware model of development. While the WC was narrowly economist in its conception of development, the PWC seeks to bring into consideration its economic and social dimensions and to rediscover the importance of politics, institutions and the state".

Then supported by José Luis Machinea statement (2007), who said; "We are witnessing the emergence of a new consensus on growth. The basic precept of this consensus is that policy outcomes depend on the context in which policy measures are applied and, therefore, vary from country to country. Hence, the lessons learned from other countries' experiences do not translate into an uncritical transposition of other countries' policy initiatives or institutional arrangements to the region. Experiences cannot be copied without taking into account of history, Social structure, external settings, political dynamics, and institutions, i.e. the specific characteristics of each country ... while it is possible to find a set of principles that are common to all successful growth strategies, there are many different ways these principles can be applied, depending on the characteristics of each country (Machinea and Kacef 2007).

Second alternative is trying offered by former Brazilian President Fernando Henrique Cardoso (1994-2005), he cited that many observers guessed his Neostructuralism method is Neoliberalism, but he himself denied several times, Cardoso said that "When I wrote my books on dependency theory, the underlying hypothesis was that the international process of capitalism adversely affected conditions for development. It did not prevent development, but made it unbalanced and unjust. Many considered economic inward-orientation was a possible form of defense against the alternative of an 
international integration regarded as risky and dangerous. This view has changed. We have to admit that participation in the global economy can be positive, that the international system is not necessarily hostile. But we should work carefully to seize the opportunities. Successful integration into the global economy depends, on the one hand, on diplomatic articulation and adequate trade partnerships, and, on the other, on the individual homework of each developing country based on a democratically built consensus".

From this statement, will be understood that Neostructuralism actually starts from the consciousness of dependency theory is not true/valid, but does not mean neoliberalism became the main alternative, there is description that the open gates of Latin America economies, in this regard is Brazil must also pay attention the aspects of readiness in domestic, so the role of the state and the strength of the domestic economy is not lost, and this is the core meant of Neostructuralism.

It is as expressed by Leiva (1998) that "neostructuralism's historical opportunity appears once it is necessary to consolidate and legitimize the new regime of accumulation originally put in place by neoliberal policies. Neoliberalism and neostructuralism, therefore, are not antagonistic strategies, but rather, due to their differences, play complementary roles ensuring the continuity and consolidation of the restructuring process".

And Neostructuralism sees the main obstacles of Latin America countries, especially Brazil in its economic development, are:

1 In technical progress with the extreme concentration of innovation and technological capability in the centre or core economies and largely under the control of TNCs;

2 In financial vulnerability as peripheral or developing countries are far more exposed to external shocks than in the past due to greater financial dependence with its associated volatility;

3 Trade vulnerability has intensified as a result of fluctuations in demand levels and terms of trade, partly due to the continued deterioration in commodity prices;

4 In the economic mobility of factors of production. While the neoliberal reforms have greatly enhanced the mobility of capital, the mobility of labour continues to be restricted. This asymmetry skews the distribution of income in favour of capital, and places labour at a disadvantage, especially in the periphery or developing countries due to their surplus of labour. 
To address these, Neostructuralism offer some economic solutions, including:

1 Enhance the transfer of technical progress from the centre to periphery countries;

2 Promote the development of institutional, social, human and knowledge capital so as to strengthen endogenous growth in countries of the periphery;

3 Ensure adequate participation in decision-making at the international level;

4 Gradually lower the barriers to labour migration, particularly from countries of the periphery to those of the core;

5 Decrease financial volatility;

6 Reduce the sizeable production and export subsidies of agricultural commodities in the centre or core economies.

\section{CONCLUSION AND RECOMMENDATIONS}

My analysis regarding economic development model showed that ideology which has been the cornerstone of economic development are not effective, it is characterized by some of the evidence that reveals the failure structuralism (socialism) and liberalism (neoliberalism) form. Countries now mostly pragmatic whereas do not care about economic models from where and what kind as long as it is effective for development and could implement, then it will be used, and it is exactly the expression of Den Xiaoping (2003) said: that no matter the cat is black or white as long as it catches mice then it is a good cat.

Besides economic activity also began no longer dichotomies to separate the role of the state or private/individual in development, in many models we can see in East Asia with a developmental state or Latin America with pink tide where the State could be an capital actor that encourages development economy, in this case the role of the state and the private sector increasingly inseparable. The refutation theory of the structure and dependencies based on developing countries which have the advantage on raw commodities and developed countries (north) which has the advantage of secondary or manufacture goods ultimately need each other (interdependence) and therefore must be created order of economic cooperation tightly between developing countries and developed countries (Hart and Spero: 2010).

Related synthesis, I agree with the views of Anthony Giddens, Jurgen Habermas, even Murtaza Mutahhari that the world order will be integral, which limits both at the level 
of knowledge and ideology have interrelatedness relation to one another, not least in the realm of trade and economic development model, synthesis continues in almost all aspects, first the economy and politics separate is now becoming political economy, hard power and soft power is now becoming smart power and also track one diplomacy and track two diplomacy into a twin track diplomacy, the Free-Trade be Fair -Trade (Joseph E. Stiglitz and Andrew Charlton: 2005).

This phenomena indicates that the role of the State and non-state actors such as a private/individual or labor and capital can no longer be separated or even be blasted, but must be harmonized and are related to the well in order to be able to create forms of trade and development, hence it will be perfection and growth by involves all actors and eventually have positive impact for all actors. As for the criticism, in this case too looked at aspects of the State as an economic actor without regard to the important role non-state actors in policy formulation and passage of the economy, and also just centered around economic activity and the policies in encourage the process of economic development without regard to other aspects such as politic, morals or culture, for instance why the Latin American region in this aspect left behind than the new industry countries in East Asia, one factor that sets it apart is the political stability in East Asia and unlike in Latin America political turmoil, as well as high meritocracy culture in East Asia also encourage the process of economic development.

Economic development are increasingly no more constrained by the bonds of ideology but rather more pragmatic marks the era of the growing importance of knowledge in the technical aspects, especially in the study of international political economy and international trade, and in the arena of international trade is increasingly showing a growing of the new economy will have an impact on increasingly intense competition among countries, therefore it's necessary to increase the important role of international and regional institutions in keeping the international trade mechanism continues to run smoothly and fairly.

In addition, it needed to have a sophisticated global economy mechanism in preventing the impact of the economic crisis, furthermore the aspects of international trade are necessary to have special rules if hit by economic crisis, thus the trading process is still running and evade the crisis impact. And the most important is the social impact of economic development, with the global value chain, so that poor farmers at the local level who had been priced products bought cheaply capable of being able to sell their products 
abroad at a price much more expensive, and provide them to increase income and ultimately reduce poverty.

\section{REFERENCES}

Cannon, Terry and Alan Jenkins. (2003). The Geography of Contemporary China: The impact of Deng Xiaoping's. New York: Routledge is an imprint of the Taylor \& Francis Group.

Dos Santos, Theotonio. (1970). The American Economic Review, Vol. 60, No. 2, Papers and Proceedings of the Eighty- second Annual Meeting of the American Economic Association.

Gunder Frank, Andre. (1967). Capitalism and Underdevelopment in Latin America. New York: Monthly Review Press.

Leiva, F.I. (1998): Disciplining workers in 'post-neoliberal' Chile: Neostructuralism, labor flexibility and social fragmentation in the 1990s. Amherst, MA: University of Massachusetts-Amherst.

Machinea, J. L. and O. L. Kacef (2007) 'Growth and equity: in search of the "empty box"', in R. French Davis and J. L. Machinea (eds), Economic Growth with Equity. Challenges for Latin America, Basingstoke and New York: Palgrave Macmillan.

Mark F. N. Franke. (2001). Global Limits: Immanuel Kant, International Relations, and Critique of World Politics, State University of New York Press.

Mollo, M. L. R. and A. Saad Filho (2006) 'Neoliberal economic policies in Brazil (19942005): Cardoso, Lula and the need for a democratic alternative', New Political Economy.

Oatley, Thomas. (2003). International Political Economy, interest and institutions in the global economy, Second Edition. New York: Pearson Longman.

Panizza, Francisco. (2009). Contemporary Latin America: Development and Democracy beyond the Washington Consensus, New York: Zed Books.

Prebisch, Raul. (1959).“Commercial Policy in the Underdeveloped Countries,” American Economic Review.

Richard W. Mansbach and Kirsten L. Rafferty. 2008. Introduction to Global Politics. New York: Routledge.

Robert N. Gwynne and Cristóbal Kay, Latin America Transformed: Globalization and Modernity, Second Edition. London: Hodder Education, an Hachette UK Company.

Rodrik, Dani. (2006). Goodbye Washington Consensus, Hello Washington Confusion?, Harvard University.

Rostow, W. W. (1960)."The Five Stages of Growth-A Summary". The Stages of Economic Growth: A Non-Communist Manifesto. Cambridge: Cambridge University Press.

Sachs, Jeffrey. (2005). The End of Poverty: Economic Possibilities for Our Time, New York: Penguin Press.

Said, Edward W. (1979). Orientalism. Knopf Doubleday. Vintage Books: New York.

Soe, Hok Gie. (1983). Catatan Seorang Demonstran (in Indonesia), Jakarta: Lembaga Penelitian, Pendidikan dan Penerangan Ekonomi dan Sosial.

Spero, Joan Edelman and Jeffrey A. Hart. (2010). The Politics of International Economic Relations, Seventh Edition. Canada: Cengage Learning products are represented in Canada by Nelson Education, Ltd. 
Stiglitz, Joseph E. (2002). Challenging the Washington Consensus - An Interview with Lindsey Schoenfelder, New York: The Brown Journal of World Affairs.

Stiglitz, Joseph E. and Andrew Charlton. (2005). Fair Trade for All: How Trade Can Promote Development. Oxford: Oxford University Press.

Strange, Susan. (1998). Mad Money. Great Britain: Manchester University Press.

Wallerstein, Immanuel (2004). World-systems analysis: an introduction (5. print. ed.). Durham: Duke University Press.

Williamson, John. (1989). What Washington Means by Policy Reform, in: Williamson, John (ed.): Latin American Readjustment: How Much has Happened, Washington: Institute for International Economics. 